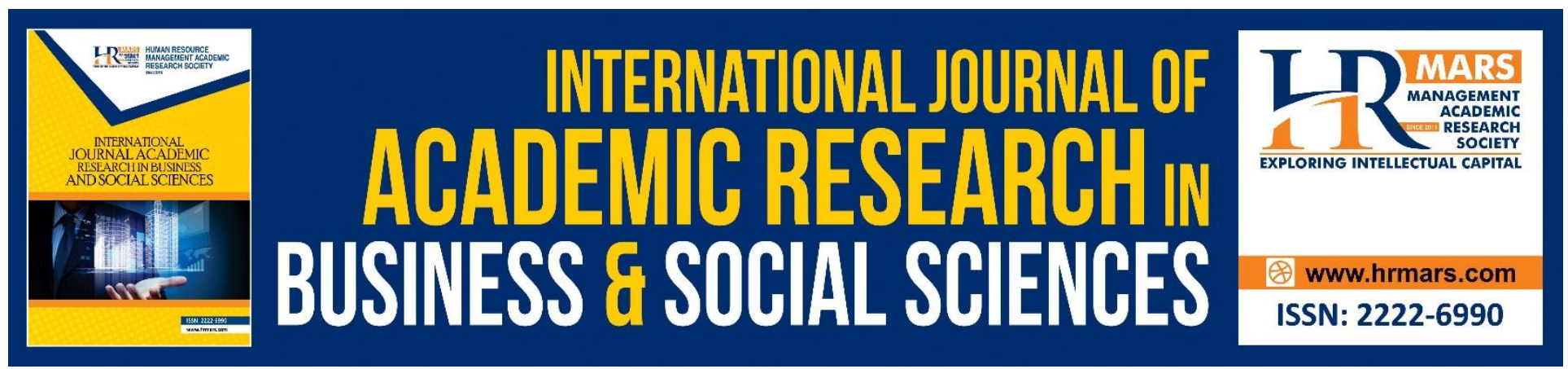

\title{
The Knowledge Management Practices at PTAR in Promoting Creativity and Innovation among Staff
}

\author{
Shahidatul Akhmam Rambeli, Alwi Mohd Yunus
}

To Link this Article: http://dx.doi.org/10.6007/IJARBSS/v8-i9/4598

DOI: $\quad 10.6007 /$ IJARBSS/v8-i9/4598

Received: 25 July 2018, Revised: 27 August 2018, Accepted: 19 Sept 2018

Published Online: 13 October 2018

In-Text Citation: (Rambeli \& Yunus, 2018)

To Cite this Article: Rambeli, S. A., \& Yunus, A. M. (2018). The Knowledge Management Practices at PTAR in Promoting Creativity and Innovation among Staff. International Journal of Academic Research in Business and Social Sciences, 8(9), 364-374.

\section{Copyright: (c) 2018 The Author(s)}

Published by Human Resource Management Academic Research Society (www.hrmars.com)

This article is published under the Creative Commons Attribution (CC BY 4.0) license. Anyone may reproduce, distribute, translate and create derivative works of this article (for both commercial and non-commercial purposes), subject to full attribution to the original publication and authors. The full terms of this license may be seen

at: http://creativecommons.org/licences/by/4.0/legalcode

Vol. 8, No. 9, September 2018, Pg. 364 - 374

http://hrmars.com/index.php/pages/detail/IJARBSS

JOURNAL HOMEPAGE

Full Terms \& Conditions of access and use can be found at http://hrmars.com/index.php/pages/detail/publication-ethics 


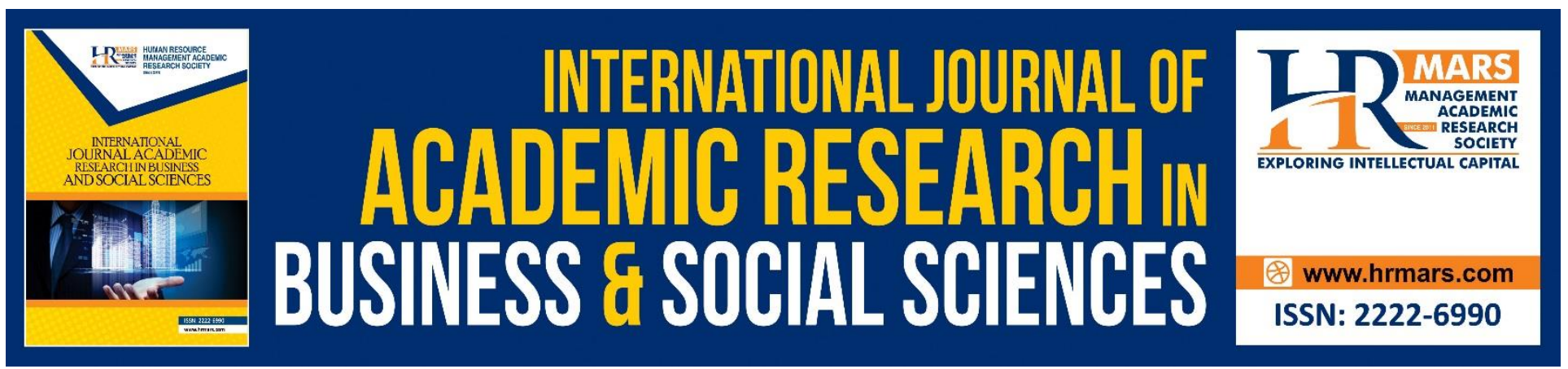

\title{
The Knowledge Management Practices at PTAR in Promoting Creativity and Innovation among Staff
}

\author{
Shahidatul Akhmam Rambeli ${ }^{1}$, Alwi Mohd Yunus ${ }^{2}$ \\ Faculty of Information Management, MARA University of Technology (UiTM), Shah Alam, Selangor, \\ MALAYSIA. \\ Email: 1'shahidatul@salam.uitm.edu.my, 2alwiyunus@salam.uitm.edu.my
}

\begin{abstract}
Creativity and innovation in organization is the realm of knowledge management direction. If properly nurtured and laid down within organizational culture, it will help organization to develop creative and innovative output. It can also increase productivity and diffusing effectiveness and efficiency in product and services. Within library management services, it will spur innovative output of services. Normally, such creative, innovative idea is derived from staff's idea called as tacit knowledge. It is then transformed into creativity and innovative project. Promoting innovative and creative culture as well as giving staffs the opportunity to share their idea, insights, abilities and experience will give value to library services. These practices are able to improve staff competencies and it is achievement in KM implementation. In Perpustakaan Tun Abdul Razak (PTAR ICC) of Universiti Teknologi MARA Kampus Puncak Alam, such practices are welcomed and become platform where staffs generate and share idea for improving library product, process and services. This paper looks into the KM initiatives and practices at PTAR ICC through several projects. The purpose of this paper is to discover KM practices to encourage staff to share creativity and innovative in organization. The findings show that ICC is a KM practices at PTAR in promoting creativity and innovation among staff.
\end{abstract}

Keyword: Creativity, Innovation, Knowledge Management, Library, ICC, PTAR, KM Practices, Tacit knowledge

\section{INTRODUCTION}

Today, many organizations have been concerned about creating, acquiring, communicating and sharing knowledge to enhance the organizational value. They realized that Knowledge Management (KM) is an important culture and practices that need to build among staff in order to keep their intangible knowledge as an asset in an organization. Knowledge occurs when information is combined with experience, context, interpretation and reflection. KM practices focus on organizational staff in order to improve their performance, competitive advantage, innovation, sharing idea and experience and at the end to get continuous improvement of the organization. Although knowledge management (KM) purposely is created for profit organizations, but nowadays 
INTERNATIONAL JOURNAL OF ACADEMIC RESEARCH IN BUSINESS AND SOCIAL SCIENCES

Vol. 8, No. 9, Sept. 2018, E-ISSN: 2222-6990 @ 2018 HRMARS

it also be practice to the nonprofit sectors such as libraries. It happens because the ultimate aim of $\mathrm{KM}$ is to increase the effectiveness and efficiently of the libraries services.

As we know, new knowledge comes from an individual idea. This knowledge then become valuable if it be transformed into organizational knowledge and the process of transforming can be done through sharing session, but it is the major challenge. Based on that, the library need to takes an initiative to create a KM practices among staff to makes the staff eager to access, locate and need to retrieve new information and knowledge. The process of sharing and communication of new knowledge will help staff to be creative and innovative. KM needs communication, collaboration, and document sharing in libraries to make consistency of work especially to their user. Knowledge that can be captured and communicated will help libraries to become more productive, effective, and successful.

In libraries, the purpose of KM practices is more to provide library with quality product and services. It is a credit if the library staff able to share idea in term to create new and effective product, process and services. It activities covers collecting, developing and managing library collections and materials, capturing new knowledge from creative and innovative project, sharing session, workshop and others that finally can give advantages not only for the libraries staff but to their customer. In addition, KM provides innovative and cost effective solution to the library users. Studies conducted by Jelenic (2011) mentioned knowledge management is a prominent role to enhance staff efficiency and effectiveness through their innovation capabilities, as a result it can increase organizational profits and reduce costs.

In addition, Kang and Kim (2013) stated, the effectively of organizational manage their knowledge is to develops a higher level of innovation and competitive advantage among staff. Innovation derive from new ideas are key factors to the development and success of the library. It requires a well-planned system that enables the firm in knowledge creation, dissemination and application. It shows that in practicing KM element, library able to promote and encourage staff with creativity and innovative.

\section{LITERATURE REVIEW}

Knowledge Management (KM) formally established in the late 1980s is a new scientific field in organization (Dalkir, 2011). In the library environment, application of KM able to improves library operational effectiveness, such as improved access to the information (Islam, Siddike, Nowrin \& Naznin, 2015). Studied conducted by Bedford, Donley and Lensenmayer (2015), highlight "a knowledge society is one in which all members of a society engage in knowledge transactions in the business environment, in the social sphere, in civic activities, and in everyday environmental actions". Explicit knowledge (recorded), tacit knowledge (personal experience) and cultural knowledge are the component in KM. Liebowitz (2011) in her studied explains there are three groups will get the benefits of KM: staff, communities of practice and organization.

In a context of staff, benefits of KM able to help staff do their jobs and save time through better decision-making and problem-solving. So, the right decision will help them to get better result in any situation. In addition, KM can build a sense of community bonding within the organization. It is good for all staff in organization to work together and have strong commitment. Apart from that, 
INTERNATIONAL JOURNAL OF ACADEMIC RESEARCH IN BUSINESS AND SOCIAL SCIENCES Vol. 8, No. 9, Sept. 2018, E-ISSN: 2222-6990 @ 2018 HRMARS

KM also helps staff to keep up to date with the latest information and situation in organization. In other hand, KM can provide challenges and opportunities to contribute among staff in organization.

Community of practice can reach benefits from KM implementation through developing professional skills and to promotes peer-to-peer mentoring. It is good for the future career development. Furthermore, KM will facilitate more effective networking and collaboration in a context outside of the organization. Networking and collaboration is important element in sharing information then to create knowledge community. In order to develop a professional code of ethics that members can adhere to is one of the benefits that community can get from KM. At last but not least, it is important to develop a common language among community from KM.

The important part implementation of $\mathrm{KM}$ is benefits for the organization. It will helps drive strategy, solves problems quickly, diffuses best practices, improves knowledge embedded in products and services, cross-fertilizes ideas and increases opportunities for innovation. It also enables the organizations to better stay ahead of the competition and KM help to builds organizational memory which is it can be retrieved whenever needed.

Alipour, Idris and Karimi, (2011) describe, KM is important part to promote knowledge creation, knowledge sharing, and knowledge utilization of the organization. Gilaninia, Ganjinia, Babaei and Mousavian (2011) stated that knowledge management consists of Knowledge Creation, Knowledge Acquisition, Organizational Learning, Knowledge Sharing, Knowledge Utilization and Knowledge Storage. Furthermore, KM is a tool that can help the libraries to improve effectiveness (Townley, 2001). The process for library staff in helping to formulate and interpret knowledge come from innovation, creativity and the ability to generate new ideas (Rikowski, 2000). Bardin (2006) mentioned there are three psychological aspects requires in creativity: i. Cognitive factors (intelligence and knowledge), ii. Conative factors (motivations, emotions, personality characters) and iii. Environmental factors (cultural, professional, social, economic context).

Creativity of employees implies new generation and valuable potential ideas about new products, services, production methods and voluntary process (Li, Sanders \& Frenkel, 2012). Creativity is generating idea also called as divergent thinking while innovation is putting the ideas into action or known as convergent thinking. Creativity is coming up with new ideas but it is not enough if the ideas unable turning it into action. Carmeloz-Ordaz, Garcia-Cruz, Sousa-Ginel and Valle-Cabrera (2011) also showed a positive influence of knowledge sharing on innovation capabilities. But, what are the practices in organization to encourage staff in promoting their creative and innovative. How to attract them in order to share their new ideas in order to improve library services?. Previous studies have failed to express the right way how the organizational be able to get best staff creativity and innovative even the sharing session is important influence in KM. Apart from that, the existing research by Ologbo, Md Nor and Okyere-Kwakye (2015) suggest that managers should provide a platform that would encourage employees to exchange their knowledge resources. Based on these supports, this study would attempt to examine the KM practices that encourage staff in creative and innovation capabilities.

In the KM environment, libraries face the challenge to get trust from the staff in term of knowledge-sharing. The management has to convinced staff that the tacit knowledge that they have 
INTERNATIONAL JOURNAL OF ACADEMIC RESEARCH IN BUSINESS AND SOCIAL SCIENCES

Vol. 8, No. 9, Sept. 2018, E-ISSN: 2222-6990 @ 2018 HRMARS

can be transform to explicit then is going to be used for the sake of the library. They need to demonstrate special knowledge with innovative abilities. Application of KM in libraries is a useful solution for promoting knowledge innovation.

\section{KNOWLEDGE MANAGEMENT PRACTICES AT PTAR}

The primary purpose of the study is to examine how Perpustakaan Tun Abdul Razak Library (PTAR) Shah Alam encourages their staff in innovative and creative through KM practices. The achievement from the projects then makes PTAR as well-known library in producing many innovative and creative products as well as services then it applicable in the library. A part from that, PTAR is capable to deliver the effective and efficient service to their user. PTAR mission is to enhanced staff competence through career advancement in academic improvement, ongoing training, study visits, industrial training, 'on the job attachment' and others. As an academic library in UiTM, PTAR responsible to provide various resources and services and up-to-date library technology to support learning and research by delivering quality services as well as providing a comfortable and friendly environment for all UiTM residents. PTAR have 5 department and support with 17 divisions. Each division has their function to run services smoothly.

Staff in the library has idea especially who those have an experience and insight with their work. But, the problems occur among them is they feel a gap and barrier to share their idea with others even it can give benefits to the organization. In organization, KM element is important to make continuous improvement and the process involved of creating, sharing, using and managing the current knowledge and information of an organization. It need participant of each level in the organization. That is the way PTAR do and practices in promoting the creativity and innovation through Innovative and creative group (ICC).

PTAR take an opportunity from the platform of ICC to encourage staff to share idea and creativity in order to create and improve library product and services. PTAR puts all effort to expose staff with ICC concept. It is a group of workers consists of 2 to 10 staff members which consists of leader, members and facilitator who will guide the group and ensure the group keep in track and able to accomplish the project during the period as plan. In addition, it is a formation of a group of worker who sit at same department or cross department with the purpose to investigate, analyze and find the way to solve the problems regarding their work by using ICC tools. Every staff can contribute ideas and opinions to the group to increasing productivity and quality of work in the library. The group members can be a combination of several of staff level in the library.

Then, group member will determine some problem occurs in the library operation and yet come out with idea for solution of each problem. After that, they will choose the best solution which can give best impact to overcome the process or service. During the session it show how the KM applied and practices, start with sharing idea, create the knowledge, using all the information and knowledge in the organization to find best solution at last innovation and creativity will exist. That's how PTAR practices the entire KM element to achieve organizational objective.

There are some projects that PTAR create and achieve higher performance at international level: 
INTERNATIONAL JOURNAL OF ACADEMIC RESEARCH IN BUSINESS AND SOCIAL SCIENCES Vol. 8, No. 9, Sept. 2018, E-ISSN: 2222-6990 @ 2018 HRMARS

Project 1

\begin{tabular}{|l|l|l|}
\hline Problem & Causes & Solution \\
\hline Book trolley difficult to handle & $\begin{array}{l}\text { i. Trolley does not move in } \\
\text { parallel } \\
\text { ii. Staff attitude who likes to } \\
\text { overload the trolley } \\
\text { iii. Uneven floor surfaces }\end{array}$ & $\begin{array}{l}\text { Assemble the absorber and } \\
\text { springs on the four trolley legs } \\
\text { manageable and capable } \\
\text { overloaded }\end{array}$ \\
\hline
\end{tabular}

Project Name: Trolly Transmitted Tracking Material Controlled With Perfectly Project Group: SMART (Staff from Client Services \& Collection Management Division) Benefit of the project:

- The trolley can be operated perfectly

- Reduce the risk of injury to staff

- Produce a comfortable environment

- Can launch the task of transmitting reading materials to the levels

Project 2

\begin{tabular}{|c|c|c|}
\hline Problem & Causes & Solution \\
\hline $\begin{array}{l}\text { Registration IT center statistic } \\
\text { delay }\end{array}$ & $\begin{array}{l}\text { i. Student write in book to } \\
\text { register IT center } \\
\text { ii. The staff is difficult to read } \\
\text { the registration book } \\
\text { iii. Staff cannot detect student } \\
\text { status } \\
\text { iv. Staff took a long time to } \\
\text { issue statistics } \\
\text { v. Staff hard to control PC } \\
\text { distribution to customers } \\
\text { vi. Registration log book is } \\
\text { easy to tear and tear } \\
\text { vii. Staff hard to control } \\
\text { check-in and check-out }\end{array}$ & $\begin{array}{l}\text { Develop in house software. } \\
\text { CLIS is an online system of IT- } \\
\text { based management system } \\
\text { accessible throughout the } \\
\text { UiTM Shah Alam Library and } \\
\text { the UiTM Library of Campus } \\
\text { Branch. }\end{array}$ \\
\hline
\end{tabular}

Project Name: CLIS system - Computer Lab Information System (online registration systems) Project Group: e-WAVE (Staff from Information \& Systems Division)

Benefit of the project:

- This system has impacted the Library in managing the IT Library Center at UITM with large student enrollment. 
INTERNATIONAL JOURNAL OF ACADEMIC RESEARCH IN BUSINESS AND SOCIAL SCIENCES Vol. 8, No. 9, Sept. 2018, E-ISSN: 2222-6990 @ 2018 HRMARS

- This system can improve staff productivity that manages IT Centers more effectively.

- This system can save time during registration and customer information access is faster and more accurate.

- The system has been successfully implemented in 9 IT Centers of UiTM Library of Shah Alam and has been used in 10 Branch Campus Libraries.

Project 3

\begin{tabular}{|l|l|l|}
\hline Problem & Causes & Solution \\
\hline $\begin{array}{l}\text { Inaccurate data of using } \\
\text { special collection }\end{array}$ & $\begin{array}{l}\text { i. No application to record } \\
\text { usage of special collection } \\
\text { ii. Difficult to trace usage of } \\
\text { special collection }\end{array}$ & $\begin{array}{l}\text { Develop in house system SCIS } \\
\text { (Special Collection Integrated } \\
\text { System) for record special } \\
\text { collection usage }\end{array}$ \\
\hline
\end{tabular}

Project Name: SCIS - Special Collection Integrated System (online registration systems)

Project Group: i-Clique (Staff from Administration, Faculty Library \& University Repository Development Department)

Benefit of the project:

- Data usage of special collection can be collected anytime and anywhere

- Staff easily to monitor user and collection

- Easy for staff to find collection needed by user

\section{KNOWLEDGE MANAGEMENT ISSUES AND SOLUTION}

Based on KM practices in PTAR, there are certain KM issues that faces are solved.

1. Tacit to Explicit Knowledge

Tacit knowledge is knowledge based on experience and observation. Here, it comes from the staff idea whereby they look into problem that needs to be solve. All the idea and the solution then transferred into written document to make it properly understand how the process happens. The explicit knowledge easily can be written down and clearly communicated to another staff as well as other people out of the library. It is tangible and easy to refer and bring to any places. Then, it be converted to a rule such as library policies and procedure to follow.

2. Knowledge Sharing

Sharing knowledge with other is not simply way, someone will keep their knowledge as a secret until meet someone who has same interest to share it. Through ICC platform, PTAR achieve to make this knowledge sharing to be practices among staff. With ICC also, sharing knowledge not only involves interaction between or among staff in the PTAR but it also can be share with other organization when it comes to competition. To share tacit knowledge requires a culture developed in the organization. It depends on the habit and willingness of staff to seek or obtain knowledge from others. 


\section{Knowledge Creation}

Create a new knowledge in the organization. In order to make the PTAR ahead from others library, creation new knowledge especially come among staff is important. Many in house systems were created and develop. Of course it did not involve big fund rather than to spend money to buy new knowledge. Knowledge creation is the act of knowing something which it comes from practice, action and interaction with others in the organization. This is important practices that driving force in creation new knowledge. Staff is able to create new knowledge from the existing process of product to make the process easier and practical.

\section{Best Practice}

PTAR has successful to make KM practices as a best practice at PTAR. Best practice is a method or technique that has been generally accepted as superior to any alternatives. Every year PTAR will make sure there is group form to involve in ICC. The management really committed on that part and it show whereby the staff will sit for the workshop on how to prepare the documentation until presentation. Before the group enters for the competition, the group will present to the management to get comment, feedback and make improvement for the project. Start in 2006 until now, PTAR looked succeed in international level from ICC platform.

\section{Competitive Advantage}

Even PTAR is not a business driven organization for making profit but competitive advantage can be applied as KM element and for sure it gives a benefit for PTAR as well as for UiTM. Competitive advantage is an attribute that allows PTAR to perform better than other library. Many organizations come to for benchmarking the KM practices in promoting creativity and innovation through ICC which is implement by PTAR. A competitive advantage includes use of existing resources, involve low cost, staff with highly skilled, commitment, geographical factor and access for the new technology.

\section{Knowledge Transfer}

The process of disseminating knowledge from one to another called as knowledge transfer. In KM practices, the good knowledge is when someone able to deliver and transfer their knowledge to another person and the person not only understand but then applied it on their daily life or task. In this scenario, ICC group in PTAR who success in promoting the creativity and innovation will transfer the knowledge for new group. It also applied for grooming a facilitator. Based on these practices, PTAR has successful in establish excellent group with great ICC project.

\section{Knowledge Community}

The KM practices showed knowledge community at PTAR is well created and develop. All the staff has their own initiative to create their own knowledge community either within department or multifunctional department. The group of staff within department who engage in knowledge-sharing activities be able to support of a common work interest by sharing their responsibility for a certain business process, a product or service, or a project that they need to complete it. While people from 
INTERNATIONAL JOURNAL OF ACADEMIC RESEARCH IN BUSINESS AND SOCIAL SCIENCES

Vol. 8, No. 9, Sept. 2018, E-ISSN: 2222-6990 @ 2018 HRMARS

multiple divisions also able to find or share something that can give value for the organization. This community also can be created broader when they join the competition and meet other community out there. Here, a community of people, groups, or teams that will share competencies, information, and knowledge in the context of a knowledge-sharing.

\section{Knowledge Based Society}

It refers to the society in PTAR at all over the country. PTAR itself have 38 libraries with 605 staff. In order to create knowledge base society among all PTAR staff in this country, staff needs to compete and success in KM practices. There are many challenges especially in librarian field in this new era. Library staff must take this opportunity and challenges in creating innovative to make library is still needed by the society in term on giving knowledge. PTAR has their own role to ensure their societies are well educated in promoting their staff to drive the innovation and creativity.

\section{FINDINGS}

PTAR has proven KM implementation and practices in promoting creativity and innovation is successful through ICC platform. Staff is encouraging to participate in developing their innovative and creative capability. A part from that, staff also can be more talented and motivated. ICC activity implies development of skills, capabilities, confidence and creativity of the people. In addition, it is a process of developing of educating and training, improving work experience and participation that will sustain staff motivation and enhance their commitment towards excellence. ICC also enhances the transformation from one that is responsive and innovative to quality-driven, cost effective in providing excellent customer service.

PTAR can use innovation as a way to create better products or services either through modifications or improvements. PTAR need to promoting innovative and creative culture as well as giving staff the opportunity to polish their abilities and improve their own competence. One of the implementation of KM in PTAR can be successfully achieve from creativity and innovative group. The ideas for creating creativity and innovation come from people who have knowledge in the library. They can be an expert person who able to making task in a form of effective and efficiently. Library staff who has an experience of their specific task can know how to solve or give some ideas to improve service delivery systems to customers. Focus on ideas, learning, knowledge sharing and value creation through identifying and problem solving strategies, analysis techniques, creative and innovative is a KM process.

KM implement has a meaningful impact on creativity of staff. Staff in each level is freely to introduce and share the idea of creativity and innovation to the organization. Then the product and services will document properly to keep as an explicit knowledge. The group member is working together to ensure that the project will present to organizational, national and international level. The organization also will give full support and it is proven when the creative product then is used at PTAR for effectiveness library task. Network can be build up with other organization during sharing session with other organization. KM helps to develop staff confident, commitment and achievement. 
INTERNATIONAL JOURNAL OF ACADEMIC RESEARCH IN BUSINESS AND SOCIAL SCIENCES Vol. 8, No. 9, Sept. 2018, E-ISSN: 2222-6990 @ 2018 HRMARS

\section{CONCLUSION}

PTAR has successful in developing creativity and innovation culture among its staff and organization itself by practicing KM element and initiative. ICC has an effective role in creating a creative and innovative atmosphere among the staff in an organization. There are many achievements that PTAR get it from ICC project even at international level. Therefore, PTAR should focus and keep it the culture where the staff able to create a creative and innovative product and services. Knowledge can be spread across the organization more freely and also, staff will feel they have an important role in creating, capturing and sharing the knowledge in an organization. It is how PTAR show the appreciation towards staff idea. Therefore, it can be concluded that the more PTAR gives freedom to its staff to act more cooperatively, the more PTAR will be successful in achieving, creating, developing and employing knowledge.

$\mathrm{KM}$ as the efforts to capturing required knowledge, sharing information in an organization. It helps the organization to generate competitiveness among other. The organization capable to recognize potential staff with their tacit knowledge and used it in solving library problem. In staff context it can boosts competence, promotes self-confidence and directs to achieve productivity. An important element for KM implementation in organizational is a creation culture in supporting learning, sharing and use of knowledge among staff. All the tacit knowledge can be share and transfer to explicit knowledge and it became high value for the organization. Another important factor of successful in KM practices is come from the top management support and commitment to encourage and appreciation to their staff. In other words, this study submits that employees " participation in knowledge sharing process would most probably enhance their ability to generate new ideas for product and service development.

\section{REFERENCES}

Alipour, F., Idris, K. and Karimi, R. (2011). Knowledge creation and transfer: Role of learning organization. International Journal of Business Administration, 2(3), 61.

Bardin, D. (2006), Management de la creativite en entreprise, Economica, Paris

Bedford, D. A., Donley, J. K., \& Lensenmayer, N. (2015). The role of librarians in a knowledge society: Valuing our intellectual capital assets. In Current Issues in Libraries, Information Science and Related Fields (pp. 81-113). Emerald Group Publishing Limited.

Camelo-Ordaz, C., Garcia-Cruz, J., Sousa-Ginel, E. and Valle-Cabrera, R. (2011). The influence of human resource management on knowledge sharing and innovation in Spain: the mediating role of affective commitment, The International Journal of Human Resource Management, 22 (7), 1442-1463.

Dalkir, K. (2011). Knowledge management in theory and practice. Cambridge, Mass: MIT Press.

Gilaninia, S., Ganjinia, H., Babaei, Z. and Mousavian, S. J. (2011). Dimensions of Knowledge Management on Good Urban Governance (Case Study: Municipality of Rasht City, Iran). Journal of Management and Strategy, 2(3), 91. 
INTERNATIONAL JOURNAL OF ACADEMIC RESEARCH IN BUSINESS AND SOCIAL SCIENCES

Vol. 8, No. 9, Sept. 2018, E-ISSN: 2222-6990 @ 2018 HRMARS

Islam, M. S., Siddike, M. A. K., Nowrin, S., \& Naznin, S. (2015). Usage and applications of knowledge management for improving library and information services in Bangladesh. Journal of Information \& Knowledge Management, 14(03), 1550026.

Jelenic, D. (2011, June). The importance of knowledge management in Organizations-with emphasis on the balanced scorecard learning and growth Perspective. In Management, Knowledge and Learning, International Conference.

Kang, M., \& Kim, B. (2013). Embedded resources and knowledge transfer among R\&D employees. Journal of Knowledge Management, 17(5), 709-723.

Li, X., Sanders, K. and Frenkel, S. (2012). How leader-member exchange, work engagement and HRM consistency explain Chinese luxury hotel employees' job performance. International Journal of Hospitality Management, 31(4), 1059-1066.

Liebowitz, J., 2011. Introduction to knowledge management. In: Dalkir, K., Liebowitz, J. (Eds.), Knowledge Management in Theory and Practice. MIT Press, Cambridge, MA, pp. 1-30.

Ologbo, A. C., Md Nor, K. and Okyere-Kwakye, E. (2015). The influence of knowledge sharing on employee innovation capabilities. International Journal of Human Resource Studies, 5(3), 102.

Rikowski, R. (2000). The knowledge economy is here-but where are the information professionals?. Business information review, 17(3), 157-167.

Townley, C. T. (2001). Knowledge management and academic libraries. College \& research libraries, 62(1), 44-55. 